\title{
Memaknai Turunnya Skor Indeks Persepsi Korupsi Indonesia Tahun 2020
}

\author{
Wawan Heru Suyatmiko \\ Transparency International Indonesia
}

wsuyatmiko@ti.or.id

\begin{abstract}
Corruption, pandemic, democracy and investment are factors reflected in the Corruption Perceptions Index score 2020. The relations between Covid-19 pandemic handling and corruption; political integrity and democracy in the policy-making process to the important political decisions that prone to cause political corruption; including the risk of corruption in the business convenience's problems during the pandemic handling and the economic recovery are the interlocked portrays of the Corruption Perception Index 2020. Declining of the Indonesian Corruption Perception Index score in 2020 to 37 indicates eradicating corruption efforts during pandemic situation are still a long way with the common aspiration and goal.
\end{abstract}

Keywords: Corruption, Democracy, Index, Perception

\begin{abstract}
Abstrak
Korupsi, pandemi, demokrasi dan investasi adalah faktor-faktor yang terefleksi dalam skor Indeks Persepsi Korupsi tahun 2020. Relasi antara penanganan pandemi Covid-19 dengan korupsi; integritas politik dan demokrasi pada proses pembuatan kebijakan hingga pengambilan keputusan politik penting yang berpotensi menghadirkan korupsi politik; sampai dengan risiko korupsi dalam problem kemudahan berusaha selama masa penanganan pandemi Covid-19 dan pemulihan ekonomi yang dalam waktu bersamaan terjadi pemangkasan sejumlah proses bisnis hingga potensi resentralisasi; adalah kelindan yang dipotret dalam Indeks Persepsi Korupsi 2020. Turunnya skor Indeks Persepsi Korupsi Indonesia pada tahun 2020 menjadi 37 menandakan masih jauhnya upaya pemberantasan korupsi di tengah situasi pandemi yang melanda dengan cita-cita dan harapan bersama.
\end{abstract}

Kata Kunci: Korupsi, Demokrasi, Indeks, Persepsi 


\section{Pendahuluan}

Korupsi merupakan sebuah kejahatan luar biasa. Secara jamak, korupsi telah dipahami sebagai sebuah penyalahgunaan kekuasaan yang telah dipercayakan kepada seseorang untuk meraup keuntungan pribadi dan golongannya. Korupsi telah mengikis kepercayaan, melemahkan demokrasi, menghambat pembangunan ekonomi dan semakin memperburuk ketimpangan, kemiskinan hingga krisis lingkungan.

Tiap tahun Transparency International, sebuah organisasi nonPemerintah tingkat global mengeluarkan sebuah hasil survei tentang korupsi. Hasil survei yang dirilis setiap tahunnya dikenal sebagai Indeks Persepsi Korupsi (biasa disebut sebagai Corruption Perception Index, selanjutnya disebut sebagai CPI). Skor CPI adalah sebuah gambaran tentang situasi dan kondisi korupsi pada level negara atau teritori (Transparency International, 2021).

Secara metodologi, CPI adalah komposit atas sejumlah indeks dari sekian lembaga survei bergengsi di tingkat global. Setidaknya terdapat 13 sumber data yang dikeluarkan oleh 12 lembaga internasional yang kredibel. CPI mengumpulkan data dari sejumlah sumber berbeda yang memberikan persepsi di kalangan pelaku bisnis dan para pakar tentang tingkat korupsi di sektor publik. Di mana skor 0 dipersepsikan sebagai kondisi yang korup dan skor 100 sebagai kondisi yang dipersepsikan bersih dari korupsi. Jadi, semakin tinggi angka skor CPI sebuah negara maka persepsinya semakin bersih.

Sebaliknya semakin rendah angka skor CPI maka persepsinya juga semakin korup.

Meski dengan segala keterbatasan atas hasil survei dan metodologi yang dipakai, namun patut diakui bahwa CPI (dan Survei Pengendalian Korupsi dari Bank Dunia) merupakan salah satu kajian yang komprehensif dan robust. Secara kuantitatif dan statistika, indikator korupsi berbasis survei agregat adalah ukuran paling valid dari gambaran keseluruhan korupsi di banyak negara. Namun, dalam setiap kasus, hasil awal yang menggunakan satu indikator harus dicek silang dengan penggunaan indikator lainnya, karena ada beberapa perbedaan kecil antara bagaimana antar indikator tersebut disusun (Hamilton dan Hammer, 2018).

\section{Korupsi dan Pandemi}

Korupsi dan keadaan darurat saling mempengaruhi, menciptakan lingkaran setan dalam melakukan kesalahan pada manajemen dan krisis yang lebih dalam. Sumber daya fiskal dalam jumlah besar yang dibutuhkan untuk menangani keadaan darurat, kebutuhan mendesak dalam penyaluran bantuan atau paket stimulus ekonomi dan risiko pengaruh yang tidak semestinya atas tanggapan kebijakan membuat peluang yang sempurna untuk korupsi. Pada gilirannya, situasi ini hanya merongrong keadilan dan kesetaraan masyarakat sepanjang penanganan respon krisis. Penanganan pandemi Covid-19 di seluruh dunia secara sempurna menggambarkan kebutuhan akan integritas dalam pengelolaan krisis. Bahkan dalam rilis global, Ketua Dewan Pengurus Transparency International, Delia Ferreira Rubio, menyatakan bahwa pandemi Covid-19 bukan hanya (sekadar) krisis kesehatan dan ekonomi. Namun juga krisis bagi korupsi dan demokrasi (Transparency International Indonesia, 2021).

Dengan dirilisnya CPI 2020, Transparency International melihat bagaimana korupsi merusak kapasitas negara untuk menanggapi keadaan darurat seperti krisis ganda; kesehatan dan ekonomi yang disebabkan oleh 
pandemi Covid-19. Di beberapa negara, korupsi telah mengalihkan sumber daya publik dari layanan penting seperti perawatan kesehatan. Kurangnya transparansi dalam alokasi sumber daya sebuah praktik yang secara positif terkait dengan korupsi - melemahkan efisiensi setiap negara saat merespon krisis; Negara-negara yang kinerjanya buruk dalam pengendalian korupsi cenderung melanggar HAM dan norma demokrasi dalam penanganan pandemi Covid-19 (Vrushi dan Kukutscha, 2021).

Di Asia, negara-negara dengan pertumbuhan ekonomi utama seperti India (40), Indonesia (37) dan Bangladesh (26) mengalami kemajuan yang lamban dalam upaya anti-korupsi, dengan beberapa komitmen pemerintah untuk melakukan reformasi belum terwujud secara efektif. Maladewa (43), yang naik 14 poin pada indeks sejak tahun lalu, menunjukkan tren positif dan mengalami kemajuan dalam ruang demokrasi dan penghapusan beberapa undang-undang yang represif (Transparency International, 2021).

Di Indonesia, bahkan ex-Menteri Sosial, Juliari Batubara, ditangkap oleh Komisi Pemberantasan Korupsi atas tuduhan melakukan korupsi pengadaan bantuan sosial terkait dengan penanganan pandemi Covid-19. Seperti dilansir oleh KPK, Juliari didakwa telah merugikan negara sebesar 14 Miliar Rupiah karena korupsi tersebut. Kini publik di Indonesia menantikan babak selanjutnya di pengadilan untuk melihat putusan pengadilan terhadap dakwaan tersebut (Komisi Pemberantasan Korupsi, 2020).

\section{Metodologi}

Tulisan ini hendak mengulas tiga hal tentang temuan CPI 2020, yakni: (1) Bagaimana memaknai turunnya skor CPI 2020 ? (2) Apa saja yang melatarbelakangi turunnya skor CPI 2020? (3) Upaya atau strategi seperti apa untuk meningkatkan skor CPI di masa depan? Tiga pertanyaan kunci inilah yang hendak dijawab dalam tulisan berikut ini.

Untuk menjawab tiga pertanyaan di atas, penulis menggunakan sumber data primer dan sekunder pada CPI 2020 serta melakukan studi literatur dan media. Tulisan ini mengelaborasi sejumlah data dan informasi yang berbentuk tabel dan grafik disajikan agar mudah dipahami dan dianalisi lebih lanjut.

CPI sendiri secara metodologi adalah merupakan sebuah indeks komposit. Metodologi mengikuti empat langkah dasar: pemilihan data sumber, penskalaan ulang data sumber, menggabungkan data yang diskalakan ulang, dan kemudian melaporkan ukuran ketidakpastian. Proses penghitungan juga menggunakan mekanisme kendali mutu yang ketat yang terdiri dari penghitungan independen paralel yang dilakukan oleh dua peneliti internal dan dua penasihat akademis yang tidak berafiliasi dengan Transparency International.

\section{Pembahasan}

\section{Rekam Jejak Indeks Persepsi Korupsi di Indonesia}

Pada tanggal 28 Januari 2021, Transparency International merilis hasil survei CPI untuk yang ke-25. Peluncuran CPI 2020 dihajat saat situasi dunia masih diliputi oleh pandemi Covid-19. Semua negara tidak terkecuali menghadapi krisis ganda, yakni krisis kesehatan dan ekonomi secara bersamaan. Sejumlah temuan dan kajian Transparency International menyatakan bahwa korupsi yang merusak pelayanan publik juga berpotensi sepanjang penanganan Covid-19 dalam sektor kesehatan. Negara-negara dengan tingkat korupsi yang tinggi terbukti sangat gagap dalam menangani pandemi. Sedangkan negara yang relatif bersih dari korupsi juga harus menghadapi situasi 
resesi ekonomi dan kemungkinan pembatasan sejumlah partisipasi publik

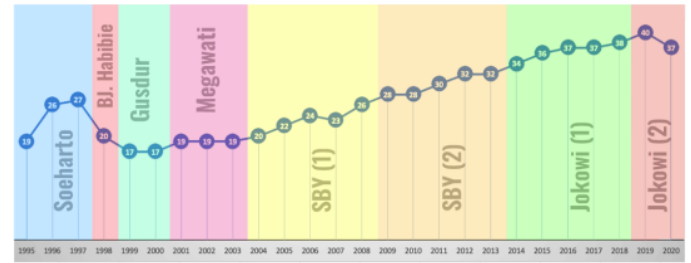

dalam ruang demokrasi.

Gambar 1. Skor IPK/CPI Indonesia dari 1995 hingga 2020

Indonesia sejak pertama kali CPI diluncurkan tahun 1995 selalu menjadi negara yang senantiasa diteliti. CPI Indonesia tahun 2020 berada di skor $37 / 100$ dan berada di peringkat 102 dari 180 negara yang disurvei. Skor ini turun 3 poin dari tahun 2019 lalu yang berada pada skor 40/100.

Pada tahun 2019, skor CPI Indonesia adalah 40/100, di mana skor ini adalah pencapaian tertinggi dalam perolehan skor CPI Indonesia sepanjang 25 tahun terakhir. Saat peluncuran CPI tahun 2019, Transparency International telah "mengingatkan" Indonesia agar lebih waspada dan terus berkomitmen dalam pemberantasan korupsi. Dengan skor 40 di tahun 2019, perekonomian dan investasi berkembang secara menjanjikan. Namun di lain pihak kebebasan masyarakat sipil dan lembaga pengawasan dilemahkan secara sistematis. Kemandirian dan efektivitas komisi antikorupsi Indonesia, Komisi Pemberantasan Korupsi (disingkat KPK), telah mengalami kemunduran. KPK dipandang sebagai simbol kemajuan dan modernisasi dalam pemberantasan korupsi. Akan tetapi kehilangan independensinya setelah terjadi perubahan undang-undang pada akhir tahun 2019 (Komisi Pemberantasan Korupsi, 2019). Secara paradoks, agenda Presiden Widodo mengutamakan investasi dan ekonomi telah mengabaikan masalah korupsi yang menjadi pusat perhatian. Indonesia berisiko membuat investor takut dan memperlambat kemajuan ekonomi.

Di sisi lain, tugas berat memberantas korupsi di seluruh sistem politik Indonesia tetap menjadi tantangan. Secara khusus, membasmi hubungan korup antara pejabat negara, pegawai negeri, penegak hukum, dan pelaku bisnis harus menjadi prioritas. Pandangan ini juga selaras dengan teori ekonomi-politik strukturalis, yang meyakini bahwa korupsi politik merupakan induk dari segala bentuk korupsi di dalam struktur negara (Hadiz, 2005; Robison, 2013, Winters, 2009).

Partai politik juga harus menunjukkan komitmen yang lebih besar terhadap transparansi dan penegakan langkah-langkah antikorupsi, dan berbuat lebih banyak untuk mengakhiri impunitas. Untuk mendorong transparansi, partai politik harus terbuka tentang pendanaan politik mereka. ${ }^{1}$ Sebagai misal KPK dan LIPI yang telah menerbitkan panduan tentang sistem integritas pada partai politik yang mesti ditegakkan oleh partai politik.

Dalam pendekatan ekonomi-politik, analisis tentang "siapa mendapat apa, bagaimana dan kapan?" menjadi suatu hal yang berelasi erat dengan korupsi politik (Laswell, 1936). Sehingga distribusi kekuasaan harus selaras karena jika kelompok yang kuat tidak mendapatkan distribusi manfaat yang dapat diterima dari struktur kelembagaan mereka akan berusaha untuk mengubahnya (Khan, 2010).

Sehingga tidak mengherankan jika sejumlah pakar bahkan pejabat negara telah memprediksi kejatuhan skor CPI Indonesia pada tahun 2020 ini. Perubahan sejumlah kebijakan yang meminimkan 
partisipasi publik marak terjadi sepanjang tahun 2020. Sebut saja revisi sejumlah undang-undang krusial, seperti UU KPK, UU MK, dan UU Minerba dan undangundang , sedikit banyak telah mempengaruhi penurunan skor CPI 2020.

\section{Temuan Kunci Dalam CPI 2020}

Seperti telah dikemukakan di atas, bahwa CPI adalah indeks komposit. Di Indonesia terdapat sembilan sumber data/indikator yang menyusun CPI 2020 ini.

Tabel 1. Indikator penyusun IPK/CPI 2020 dan 2019

\begin{tabular}{|c|c|c|}
\hline Indikator & 2020 & 2019 \\
\hline $\begin{array}{l}\text { PRS } \\
\text { International } \\
\text { Country Risk Guide }\end{array}$ & 50 & 58 \\
\hline $\begin{array}{l}\quad \text { IMD World } \\
\text { Competitiveness } \\
\text { Yearbook }\end{array}$ & 43 & 48 \\
\hline $\begin{array}{lr}\quad \text { Global } & \text { Insight } \\
\text { Country } & \text { Risk } \\
\text { Ratings } & \end{array}$ & 35 & 47 \\
\hline $\begin{array}{l}\text { World } \\
\text { Economic Forum } \\
\text { EOS }\end{array}$ & 46 & 46 \\
\hline $\begin{array}{l}\quad \text { Bertelsmann } \\
\text { Foundation } \\
\text { Transform Index }\end{array}$ & 37 & 37 \\
\hline \begin{tabular}{l}
\multicolumn{2}{c}{ Economic } \\
Intelligence Unit \\
Country Ratings
\end{tabular} & 37 & 37 \\
\hline $\begin{array}{l}\text { PERC Asia Risk } \\
\text { Guide }\end{array}$ & 32 & 35 \\
\hline $\begin{array}{l}\text { Varieties of } \\
\text { Democracy }\end{array}$ & 26 & 28 \\
\hline $\begin{array}{l}\text { World Justice } \\
\text { Project - Rule of } \\
\text { Law Index }\end{array}$ & 23 & 21 \\
\hline
\end{tabular}

Dalam Tabel 1 nampak bahwa sebagian besar indikator terjadi penurunan yang signifikan. Dari sejumlah indikator penyusun CPI 2020 terdapat lima sumber data yang merosot dibanding temuan tahun 2019 lalu. Yakni Global Insight yang merosot hingga 12 poin; $P R S$ yang merosot 8 poin; IMD World Competitiveness Yearbook yang turun 5 poin, PERC Asia turun sebesar 3 poin dan
Varieties of Democracy yang juga turun 2 poin dari tahun lalu. Sementara itu, tiga dari sembilan indeks mengalami stagnasi, yakni World Economic Forum EOS; Bertelsmann Transformation Index dan Economist Intelligence Unit. Sedangkan satu indikator mengalami kenaikan sebanyak dua poin yakni World Justice Project - Rule of Law Index. Meski indikator ini mengalami kenaikan namun secara agrerat tidak mampu mempengaruhi kontribusi penurunan CPI 2020 ini. Sebab dalam lima tahun terakhir WJP-ROL Index selalu di bawah rerata skor CPI tahunan.

\section{Analisis Per Indikator}

Memaknai turunnya agregat CPI 2020 bisa dipahami dengan menganalisis per indikator penyusunnya. Penulis akan memulai dari indikator yang mengalami penurunan paling signifikan. Pertama, Global Insight Country Risk Rating, yang mengalami penurunan hingga 12 poin dari tahun 2019 ke 2020. Indikator dalam Global Insight Country Risk Rating menilai tentang risiko bahwa individu/perusahaan akan menghadapi suap atau praktik korupsi lainnya untuk menjalankan bisnis, agar mendapatkan kontrak hingga diizinkan untuk mengisi kuota impor/ekspor, bahkan sekadar mendapatkan dokumen sehari-hari. Hal ini mengancam kemampuan perusahaan untuk beroperasi di suatu negara, atau akan mendatangkan sanksi hukum dan yang paling merugikan adalah kerusakan reputasi bisnis (IHS Markit, 2021).

Kedua, The PRS Group International Country Risk Guide yang mengalami penurunan hingga 8 poin. PRS adalah penilaian korupsi dalam sistem politik. Bentuk korupsi paling umum yang dihadapi langsung oleh bisnis adalah korupsi keuangan dalam bentuk permintaan pembayaran khusus dan suap yang terkait dengan izin impor dan ekspor, kontrol perdagangan, penghitungan pajak, 
perlindungan polis atau pinjaman. Tindakan tersebut paling berkaitan dengan korupsi aktual atau potensial dalam bentuk patronase berlebihan, nepotisme, reservasi pekerjaan, pertukaran bantuan, pendanaan partai secara rahasia dan hubungan sangat dekat yang mencurigakan antara politik dan bisnis (politico-business) (PRS Group, 2021).

Ketiga, IMD World Competitiveness Yearbook yang turun 5 poin. IMD mengukur daya saing suatu negara dan menentukan bagaimana situasi sosialpolitik dan ekonomi suatu negara berpengaruh dalam hal daya saing perusahaan. IMD menggali sejauh mana eksistensi suap dan korupsi antara sektor bisnis dengan pelayanan publik (IMD World Competitiveness, 2020).

Keempat, PERC Asia turun sebesar 3 poin. PERC membuat berbagai laporan risiko di negara-negara Asia. PERC memberikan perhatian khusus pada variabel sosial-politik penting seperti korupsi, hak dan risiko kekayaan intelektual, kualitas tenaga kerja serta kekuatan dan kelemahan sistemik lainnya dari masing-masing negara/wilayah Asia. PERC mengukur tentang bagaimana penilaian para pebisnis terhadap masalah korupsi di negara tempat mereka beroperasi (PERC, 2018).

Kelima, Varieties of Democracy yang juga turun 2 poin. $\mathrm{V}$-Dem adalah indikator yang terbilang baru. Pada tiga tahun terakhir dimasukkan sebagai salah satu indikator bagi IPK/CPI. Indikator ini dipandang penting karena V-Dem menilai tentang seberapa luas korupsi politik terjadi di sebuah negara yang dialami oleh para ahli dan pelaku bisnis. Indeks korupsi dalam V-Dem mencakup ukuran dari enam jenis korupsi yang berbeda yang mencakup korupsi eksekutif, legislatif dan yudikatif. Di ranah eksekutif, tindakan tersebut juga membedakan antara korupsi yang sebagian besar berkaitan dengan suap, dan korupsi akibat penggelapan. Terakhir, juga membedakan antara korupsi di eselon tertinggi eksekutif dan di sektor publik pada umumnya. Dengan demikian, langkah-langkah tersebut memanfaatkan beberapa jenis korupsi yang dapat dibedakan: baik kecil maupun besar; baik penyuapan maupun penggelapan; baik korupsi yang bertujuan untuk mempengaruhi pembuatan hukum dan yang mempengaruhi implementasi. Indeks diperoleh dengan mengambil ratarata dari (a) indeks korupsi sektor publik (b) indeks korupsi eksekutif (c) indikator untuk korupsi legislatif dan (d) indikator untuk korupsi peradilan. Dengan kata lain, keempat lingkungan pemerintahan yang berbeda ini memiliki bobot yang sama dalam indeks yang dihasilkan (Varities of Democracy, 2020).

Setelah lima indikator yang mengalami penurunan, sehingga secara agregasi mempengaruhi penurunan skor CPI 2020, berikutnya penulis akan memaparkan tiga indikator yang mengalami stagnasi. Keenam, World Economic Forum EOS mengalami stagnasi pada skor 46. WEF menilai tentang Indikator ini telah berkembang dari waktu ke waktu untuk menangkap poin data baru yang penting bagi Indeks Daya Saing Global (GCI). WEF-EOS menilai tentang seberapa umum/biasa perusahaan melakukan pembayaran ekstra tanpa terdokumentasi atau suap terkait dengan impor dan ekspor, fasilitas umum, pembayaran pajak tahunan, pemberian kontrak dan lisensi publik, serta mendapatkan keputusan yudisial yang menguntungkan bagi pelaku usaha. Termasuk diantaranya adalah seberapa umum/biasa pengalihan dana publik ke perusahaan, individu, atau kelompok terkait korupsi (WEF, 2020).

Ketujuh, Bertelsmann Foundation Transformation Index. BFTI yang juga 
stagnan di angka 37 adalah sebuah indikator yang menilai tentang efektivitas pemidanaan korupsi pada pejabat publik serta tingkat keberhasilan dalam mengontrol korupsi dan efektivitas penerapa penegakan integritas pada lembaga publik (BFTI, 2020).

Kedelapan, Economist Intelligence Unit yang mengalami stagnasi di skor 37 juga. EIU adalah sebuah indikator yang sangat komprehensif yang mengukur tentang ketersediaan prosedur dan akuntabilitas yang jelas dan mengatur alokasi dan penggunaan dana publik; penyalahgunaan dana publik oleh menteri/pejabat publik untuk kepentingan pribadi atau partai politik; adanya dana khusus yang tidak ada pertanggungjawabannya; adanya penyalahgunaan sumber daya publik secara umum; Adanya pegawai negeri atau pejabat profesional yang ditunjuk langsung oleh pemerintah; Adanya badan independen yang mengaudit manajemen keuangan publik; Adanya peradilan independen dengan kekuasaan untuk mengadili menteri/pejabat publik atas pelanggaran; hingga adanya biaya pembayaran suap untuk mendapatkan kontrak dan mendapatkan bantuan (EIU, 2020).

Terakhir, satu-satunya indikator yang mengalami kenaikan adalah World Justice Project - Rule of Law Index. Dalam WJPROL salah satu yang diagregasi adalah indikator "Ketiadaan Korupsi". Indikator ini mengukur penyalahgunaan kewenangan publik pada eksekutif, legislatif, yudikatif, maupun polisi/militer (WJP - ROL, 2020). Namun mesti dicatat, meskipun indikator ini mengalami kenaikan namun secara agrerat tidak mampu mempengaruhi kontribusi penurunan CPI 2020 ini. Sebab kenaikan dua poin dalam WJP-ROL Index tidak bisa mendongkrak CPI 2020, karena di bawah rerata skor CPI tiap tahunnya (Mochtar, 2021).

\section{Analisis Trend Pada Indikator dalam Indeks Persepsi Korupsi}

Setelah analisis per indikator dilakukan, penulis juga memandang penting melakukan analisis berkelompok antar indikator dengan skor CPI sebagai acuan utama. Analisis berkelompok dilakukan dengan menarik data komposit hingga delapan tahun terakhir. Pengelompokan didasarakan pada tiga kelompok besar, yakni: (1) kelompok indikator yang selalu di atas CPI; (2) kelompok indikator yang berada setara dengan CPI; dan (3) kelompok indikator

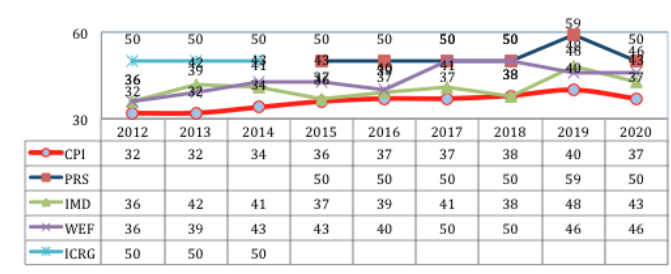

yang berada di bawah CPI 2020 .

Gambar 2. Indikator di atas skor IPK/CPI

Dalam delapan tahun terakhir setidaknya PRS, IMD dan WEF selalu berada di atas skor CPI 2020. Kelompok indikator yang selalu di atas skor CPI memberikan harapan bagi upaya perbaikan pemberantasan korupsi. Sehingga pada kelompok ini cukup dijaga konsistensi perbaikannya. Namun temuan pada CPI 2019 dan 2020 sangat disayangkan kelompok ini mengalami penurunan yang signifikan (PRS hingga 8 poin, IMD hingga 5 poin dan stagnasi pada

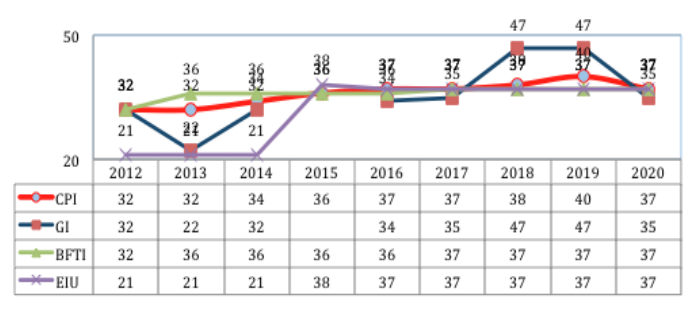

WEF).

Gambar 3. Indikator setara skor IPK/CPI 
Indikator yang setara dengan skor CPI dalam delapan tahun terakhir diantaranya adalah GI, BFTI dan EIU. Bahkan yang paling mengenaskan adalah merosotnya skor Global Insight hingga 12 poin dari tahun 2019 ke 2020 menjadi salah satu penyebab skor agregat CPI 2020 turun drastis sebanyak 3 poin, dari 40 ke 37.

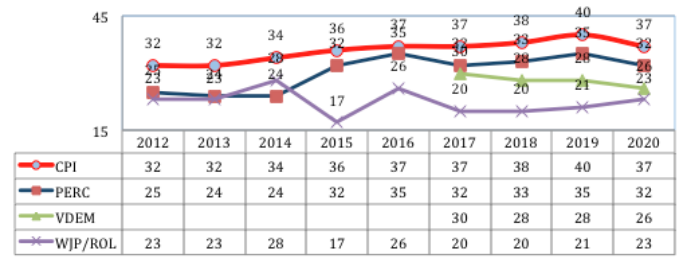

Gambar 4. Indikator di bawah skor IPK/CPI

Kelompok indikator ketiga yang selama kurun waktu delamapn tahun selalu di bawah skor rerata CPI perlu mendapatkan perhatian khusus. Diantaranya adalah PERC, V-dem dan WJP/ROL. Sehingga tidak heran jika kenaikan dua poin skor WJP-ROL dari angka 21 di tahun 2019 ke angka 23 di tahun 2020 tidak memberikan kontribusi yang signifikan pada perolehan skor agregat CPI 2020.

\section{Korupsi Pada Isu Sektoral}

\section{Sektor Ekonomi, Investasi dan Kemudahan Berusaha}

Pada CPI pengukuran tahun 2020, indeks penyusun yang berhubungan dengan kinerja ekonomi dan iklim berusaha di Indonesia hampir seluruhnya mengalami penurunan. Dominasi pendekatan pembangunan ekonomi yang digunakan Pemerintah dilihat belum banyak memberikan manfaat bagi iklim investasi Indonesia. Upaya penyederhanaan proses perizinan, terutama untuk penanaman modal asing juga telah mulai dilakukan dengan munculnya Online Single Submission (OSS). Di kemudian hari mnejadi cikal bakal lahirnya UU Cipta Kerja. Bahkan di sektor sumber daya alam dan ekstraktif misalnya melalui amandemen UU Mineral dan Batu Bara seringkali melanggar keamanan lingkungan, merampas hak masyarakat adat dan tidak memenuhi prinsip tata kelola yang baik. Selain itu, berbagai paket kebijakan deregulasi yang telah digulirkan belum sampai pada akar permasalahan utama korupsi, yaitu korupsi politik (Zuniga dan Mullard, 2018).

Tabel 2. Indikator yang berhubungan dengan ekonomi, bisnis dan investasi

\begin{tabular}{llcc}
\hline No & $\begin{array}{l}\text { Indeks } \\
\text { Penyusun CPI } \\
\text { Sektor } \\
\text { Ekonomi }\end{array}$ & $\mathbf{2 0 2 0}$ & $\mathbf{2 0 1 9}$ \\
\hline 1 & $\begin{array}{l}\text { PRS } \\
\text { International } \\
\text { Country Risk } \\
\text { Guide }\end{array}$ & 50 & 58 \\
2 & $\begin{array}{l}\text { IMD World } \\
\text { Competitiveness } \\
3\end{array}$ & 43 & 48 \\
& $\begin{array}{l}\text { Yearbook } \\
\text { Global Insight } \\
\text { Country Risk } \\
\text { Ratings } \\
4\end{array}$ & 35 & 47 \\
PERC Asia Risk & 32 & 35 \\
5 & $\begin{array}{l}\text { Guide } \\
\text { World Economic }\end{array}$ & 46 & 46 \\
Forum EOS & & \\
\hline
\end{tabular}

Penurunan di keempat indeks memperlihatkan luasnya dimensi berbisnis di Indonesia. Indikator International Country Risk Guide dan IMD World Competitiveness Yearbook yang turun menggambarkan adanya kecenderungan sektor ekonomi dikuasai oleh pihak-pihak yang memiliki kedekatan dengan aktor politik dan pembuat kebijakan sehingga lebih diuntungkan. Hal ini ditandai dari masih maraknya suap di wilayah-wilayah besar seperti penentuan izin ekspor-impor, kuota perdagangan dan penggelapan pajak.

Selain itu pada indikator Global Insight (Country Risk Rating), termasuk yang mengalami penurunan terbesar yaitu 
sebanyak 12 poin dari 47 ke 35. Indikator ini menegaskan masih sangat berisikonya menjalankan usaha atau berbisnis di Indonesia menurut para pelaku usaha dan ahli. Pada enam aspek yaitu politik, ekonomi, kerangka kebijakan, pajak dan risiko keamanan, hampir seluruhnya dianggap berisiko terhadap korupsi.

Sementara turunnya indikator Political Economic Risk Consultancy (PERC) menegaskan instansi pemerintah dan penegak hukum seperti kepolisian, pengadilan, bea cukai, pajak, perizinan, pengawasan, militer masih dianggap sumber korupsi yang menghambat kemudahan berusaha.

\section{Sektor Penegakan Hukum}

Dalam sektor penegakan hukum, ada tiga indikator penyusun yaitu Bertelsmann Transformation Index 2020, Economist Intelligence Unit Country Risk Service 2020 dan World Justice Project Rule of Law Index 2019. Dua indikator pertama mengalami stagnasi atau tidak mengalami kemajuan di angka 37, sedangkan indikator WJP ROL mengalami kenaikan dua poin dari 21 ke 23. Kenaikan indeks terakhir tidak signifikan dan tetap merupakan poin terkecil dari keseluruhan indikator penyusun CPI di Indonesia.

Tabel 3. Indikator yang berhubungan dengan penegakan hukum

\begin{tabular}{|c|c|c|c|}
\hline No. & $\begin{array}{l}\text { Indeks Penyusun } \\
\text { CPI Sektor } \\
\text { Penegakan } \\
\text { Hukum }\end{array}$ & 2020 & 2019 \\
\hline 1 & $\begin{array}{l}\text { Bertelsmann } \\
\text { Transformation } \\
\text { Index } 2020\end{array}$ & 37 & 37 \\
\hline 2 & $\begin{array}{ll}\text { Economist } & \\
\text { Intelligence } & \text { Unit } \\
\text { Country } & \text { Risk } \\
\text { Service 2020 } & \end{array}$ & 37 & 37 \\
\hline 3 & $\begin{array}{l}\text { World Justice } \\
\text { Project Rule of Law } \\
\text { Index } 2019\end{array}$ & 23 & 21 \\
\hline
\end{tabular}

Pada indikator Bertelsmann Transformation Index, para penilai mempersepsikan bahwa kinerja penegakan hukum dan efektivitas pemidanaan korupsi dalam mengontrol korupsi mengalami kecenderungan untuk tetap tidak berubah. Sedangkan stagnasi yang juga terjadi pada indikator Economist Intelligence Unit (Country Risk Rating), menegaskan tidak ada kemajuan berarti dalam penegakan kejahatan keuangan dan juga mekanisme pengawasannya.

Sedangkan pada indikator WJP - ROL yang mengalami kenaikan, perlu dilihat sebagai adanya kasus-kasus besar yang ditangani oleh Kepolisian, Kejaksaan dan juga KPK; meskipun upaya-upaya tersebut paradoks dengan sejumlah putusan Peninjauan Kembali Mahkamah Agung yang memberikan potongan masa hukuman terpidana korupsi. Sehingga hal ini pula yang menyebabkan kenaikan WJPROL yang hanya dua poin tidak memberikan signifikansi bagi agregat data CPI 2020. Kasus-kasus yang mendapatkan perhatian publik misalnya kasus dana investasi Asabri dan Jiwasraya, dan ditangkapnya buron cesie bank Djoko Tjandra.

Dalam pandangan yang terdahulu korupsi dianggap sebagai ketiadaan akuntabilitas yang paradoks dengan diskresi dan kewenangan yang terpusat pada sebuah lembaga atau bahkan satu orang tertentu, bersifat monopolitistik (Klitgaard, 1988). Pandangan ini turut dilengkapi dengan rumusan bahwa pengendalian korupsi sangat dipengaruhi oleh kendala yang terdiri dari norma dan kelembagaan serta kesempatan yang terdiri atas kewenangan dan sumberdaya. Di mana pengendalian korupsi berarti kendala harus dikurangi sedemikian rupa dengan pranata dan kesempatan untuk mencegah korupsi terjadi (MungiuPippidi, 2015). Problem integritas juga menjadi salah satu hal yang menjadi 
sangat penting. Selain kurangnya transparansi, korupsi disebabkan juga karena melemahnya nilai-nilai sosial, kepentingan pribadi menjadi lebih utama dibanding kepentingan umum, serta kepemilikan benda secara individual menjadi etika pribadi yang melandasi prilaku sosial sebagaian besar orang. Oleh sebab itu, dalam perspektif pemberantasan korupsi, integritas merupakan salah satu pandangan untuk bagi seseorang untuk mampu melawan praktik korupsi. Integritas merupakan perpaduan antara nilai akunyabilitas, kompetensi dan etika (Pope, 2000).

Sementara itu, dalam upaya penegakan hukum faktor yang berkaitan erat dengan pemberantasan korupsi adalah reformasi birokrasi dan tata kelola pemerintahan yang baik. Problem tata kelola pemerintahan biasanya dilihat dalam bentuk kualitas tata kelola. Namun mendefinisikan kualitas tata kelola pemerintahan yang baik tidak bisa hanya ditandai dengan tidak adanya korupsi. Meskipun tingkat korupsi yang tinggi jelas bertentangan dengan kualitas tata kelola yang baik. Bagi sebagian orang, pencapaian kualitas tata kelola terkait erat dengan kebijakan antikorupsi pada sebuah negara atau institusi (Rothstein, 2011).

\section{Sektor Politik dan Demokrasi}

Pada sektor ini, satu-satunya indikator penyusun CPI adalah indikator Varieties of Democracy Project 2020. Pada indikator ini, terjadi penurunan dari angka 28 di tahun 2019 menjadi 26 di tahun 2020 .

Tabel 4. Indikator yang berhubungan dengan sektor politik dan demokrasi

\begin{tabular}{llll}
\hline No. & Indeks & 2020 & 2019 \\
& Penyusun \\
& CPI Sektor & & \\
& Politik dan & & \\
& Demokrasi & & \\
\hline 1 & $\begin{array}{l}\text { Varieties of } \\
\text { Democracy }\end{array}$ & & \\
& Project 2020 & & \\
\hline
\end{tabular}

Kemunduran ini mengindikasikan bahwa selama satu tahun terakhir, sektor politik dan demokrasi terutama dalam konteks Pemilihan Umum (Pemilu) masih berisiko tinggi dari korupsi. Karakteristik klientelisme politik tampak pada pemilih, para pekerja Pemilu (aktivis partai, konsultan politik, tim sukses dll) dan aktor-aktor lain yang terlibat di dalam Pemilu memberikan dukungan kepada politisi dengan imbalan material benefit atau keuntungan personal. Sebaliknya, dalam klientelisme politik, politisi memenangi kompetisi dengan membagibagikan barang, uang cash dan berbagai fasilitas lain untuk mendapatkan suara (Aspinall dan Berenschot, 2019). Sehingga pemberantasan korupsi yang mengabaikan aspek politik dan memperlakukan reformasi (sebatas) persoalan managemen teknis adalah sebuah pandangan yang keliru dan perlu diubah. Di mana korupsi juga harus diletakkan dalam pemahaman penataan institusi/kelembagaan politik itu sendiri (Johnston, 2005).

Di sisi lain tata kelola dan integritas politik juga masih menjadi masalah besar. Hasil penelitian Marepus Corner tentang 'Peta Pebisnis di Parlemen' mengungkapkan sebanyak 55 persen atau 318 anggota DPR dari keseluruhan 575 anggota DPR merupakan pebisnis. Setidaknya rasio lima hingga enam orang dari sepuluh anggota DPR merupakan pebisnis. Temuan yang didapatkan oleh Marepus Corner dengan menganalisis profil anggota DPR periode 2019-2024 dengan kepemilikan bisnis. Sehingga potensi korupsi dalam bentuk konflik kepentingan sepanjang pembuatan undang-undang akan semakin tinggi (Serat, 2020).

Freedom House menilai Indonesia sebagai negara yang "sebagian bebas" pada tahun 2019, mencerminkan fakta bahwa negara tersebut telah mengalami 
penurunan demokrasi yang signifikan karena korupsi yang sistematis, diskriminasi yang meluas, dan maraknya praktik penganiayaan terhadap kelompok minoritas (Freedom House, 2019). Senada juga dengan temuan dari The Economist dalam Democracy Index yang menempatkan Indonesia pada posisi sebagai "The Flawed Democracy". Menurut The Economist, Indonesia mengalami penurunan skor berdemokrasi. Dari skor 6,48 pada tahun 2019 turun menjadi 6,3 pada tahun 2020 (The Economist, 2020).

\section{Peta Jalan Antikorupsi Masa Depan}

Berangkat dari sejumlah temuan dan analisis data di atas, Penulis menarik garis silang antara skor CPI dengan indikator penyusun yang direrata dalam delapan tahun terakhir.

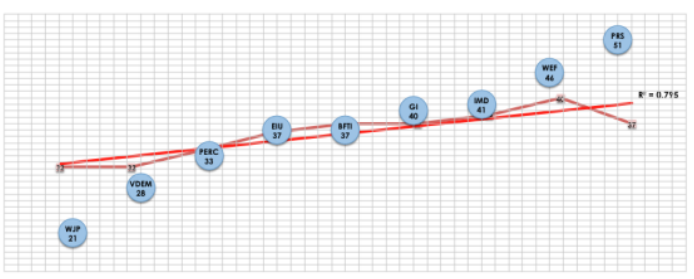

Gambar 5. Studi silang antara IPK dan indikator penyusun

Dalam Gambar 5, Penulis melakukan uji rerata terhadap sembilan indikator dalam delapan tahun terakhir dan melakukan uji regresi terhadap dinamika CPI dalam delapan tahun terakhir. Dari Gambar 5 tersebut Penulis menawarkan peta jalan perbaikan/peningkatan skor CPI dalam dua kelompok, yakni: (1) berdasarkan metodologi dan (2) berdasarkan isu sektoral. Kedua kelompok ini berkaitan satu sama lain.

Pertama, berdasarkan analisis metodologi dan olah data serta berangkat dari skor CPI terakhir, maka Pemerintah selayaknya menjaga konsistensi terhadap capaian yang telah diraih dalam bidang kemudahan iklim berusaha, invetasi dan penanaman modal. Meskipun dalam setahun terakhir terjadi penurunan yang signifikan terhadap skor yang berhubungan dengan investasi usaha, namun perlu dicatat bahwa sejumlah kebijakan yang berelasi dengan kemudahan berusaha haruslah tetap memberikan jaminan terhadap kepastian hukum dan menghilangkan korupsi dalam setiap rantai bisnisnya (Mulholland dan Sanit, 2020). Sebagai tambahan catatan, dalam survei Bank Dunia tentang kemudahan berusaha salah satu faktor yang membuat para investor enggan untuk menanamkan modalnya di Indonesia salah satunya dan paling berpengaruh adalah soal penanganan korupsi. Hal ini terkonfirmasi dalam temuan Indeks Kemudahan Berusaha yang stagnan pada tahun 2019 dan 2020 dengan skor 69,6 dan berada pada peringkat 73. Indonesia mampu menunjukkan perbaikan pada tiga indikator. Untuk indikator kemudahan memulai bisnis, Indonesia berhasil memangkas dan menyederhanakan prosedur pasca-pencatatan administratif, antara lain dalam hal administrasi pajak, jaminan sosial, dan perizinan. Sementara indikator-indikator lain yang tidak menunjukkan perbaikan adalah kemudahan dalam perizinan konstruksi, kemudahan untuk mendapatkan listrik, serta penguatan hak para kreditur dan debitur di mata hukum (World Bank, 2020).

Kedua, indikator-indikator yang cenderung setara dengan skor CPI. Indikator ini perlu dikelola agar terjadi perbaikan di masa depan. Prevalensi korupsi antara pelaku usaha, pejabat publik dan politisi merupakan kelindan serius yang mesti diperhatikan. Upaya keterbukaan informasi, prosedur dan biaya dalam setiap proses perizinan usaha, pengadaan barang dan jasa, perpajakan dan penerimaan negara mesti dikelola secara tepat dan berdampak pada upaya peningkatan nilai investasi. Problem bisnis 
yang berhubungan industri ekstraktif adalah sektor yang paling rentan terhadap potensi dan risiko korupsi. Relasi korupsi dengan sektor sumber daya alam dan industri ekastraktif sangat erat, karena posisinya secara ekonomi sangat tinggi, yang memberikan $12-38$ persen dari PDB Indonesia dengan serapan tenaga kerjanya sekitar 40 juta orang, meski dari segi pajak hanya berkontribusi sebesar 3,87 persen. Pada 2018 KPK mencatat di sektor minerba potensi kerugian yang bersumber dari kurang bayar pajak sebesar Rp15,9 triliun, belum lagi dari administrasi serta perizinan yang buruk mencapai $\mathrm{Rp} 28,5$ triliun. Selain berdampak secara finansial, korupsi sektor sumber daya alam juga berdampak pada terjadinya pengrusakan fungsi ruang (Mongabay, 2020). Sehingga relevansi untuk menghidupkan kembali "Gerakan Nasional Penyelematan Sumber Daya Alam" (biasa disingkat dengan GNPSDA) menjadi sebuah rekomendasi yang urgen (Komisi Pemberantasan Korupsi, 2018).

Ketiga, indikator-indikator yang selalu berada di bawah skor CPI perlu mendapatkan perhatian khusus dan usaha yang keras dalam menciptakan terobosan perbaikan secara kontinyu. Dalam sektor yang berhubungan dengan politik dan demokrasi yang juga cenderung di bawah skor CPI perlu dilakukan perbaikan dan peningkatan integritas politik di Indonesia. Warisan politik dari rezim terdahulu di mana sumber daya publik digunakan untuk mendapatkan dukungan dari jaringan patronase terus memainkan peran dalam lanskap politik Indonesia, bahkan setelah era demokratisasi. Berbagai bentuk patronase dan klientelisme ada di seluruh sistem politik, sebagaimana tercermin dari konsesi dan proses pengadaan yang sering diberikan berdasarkan hubungan pribadi (Transparency International dan U4 Anti Corruption Resource Centre. 2012). Selain itu, meningkatnya ketergantungan pada uang untuk kampanye politik telah menawarkan peluang terjadinya korupsi politik dan penguasaan sumberdaya publik, khususnya di tingkat lokal. Tingginya biaya kampanye politik, menyisakan pilihan bagi legislator dan anggota dewan di nasional dan pusat untuk 'menyalahgunakan kekuasaan mereka untuk mencari biaya pengganti kampanye saat memenangkan kursi legislatif dan membantu mendanai kegiatan partai mereka (Muhtadi, 2020).

Selain sektor politik dan demokrasi, indikator yang juga selalu di bawah rerata CPI tiap tahunnya adalah terkait dengan penegakan hukum. Sektor penegakan hukum masih sangat rentan terhadap korupsi. Hal ini juga terkonfirmasi atas sejumlah kasus yang menimpa para penyelenggara negara, pejabat publik bahkan penegak hukum itu sendiri. Model koordinasi dan supervisi dari KPK kepada aparatur penegak hukum lainnya menjadi hal perlu mendapatkan perhatian serius. Selain pula terkait reformasi birokrasi dan penegakan etik dalam tiap-tiap lembaga penegak hukum yang mesti ditemukan quick wins dalam tempo yang relatif pendek. Berbeda dengan cara pandang ekonomi-politik pembangunan di era 1960-an hingga 1980-an, mayoritas peneliti kajian antikorupsi kontemporer bersepakat bahwa korupsi merupakan penghambat laju pembangunan ekonomi. Karena itu, agar arus investasi asing bisa masuk ke pasar dalam negeri, maka kepastian hukum dan stabilitas sosial, politik dan keamanan menjadi syarat mutlak untuk dihadirkan (Umam, 2020). Sehingga kemandirian dan penguatan lembaga otoritas antikorupsi, seperti KPK, harus mendapatkan perhatian khusus. 


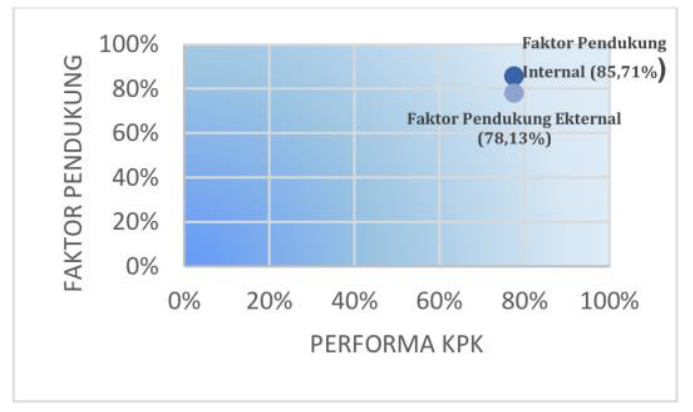

Gambar 6. Penilaian hasil kinerja lembaga antikorupsi di Indonesia

Dalam data penanganan perkara tindak pidana korupsi oleh KPK, dari tahun 2004 hingga bulan Mei 2020 terdapat 417 kasus korupsi yang melibatkan politisi dan kepala daerah, diantaranya melibatkan DPR/DPRD sebanyak 274 orang, Gubernur 21 orang dan Walikota, Bupati dan wakil sebanyak 122 orang. Data ini memberikan gambaran tentang kinerja KPK yang memberikan sumbangsih pada upaya pemberantasan korupsi. Keberhasilan KPK dalam memberantas korupsi menunjukkan bahwa kinerja lembaga otoritas antikorupsi dapat sangat efektif bahkan di dalam lingkungan pemerintahan yang buruk dan korupsi yang tinggi, serta dalam waktu yang relatif singkat. Pendekatan penting yang perlu dilakukan agar tetap menjaga kinerja KPK adalah memastikan independensi lembaga otoritas antikorupsi tetap berjalan. Para pembuat kebijakan harus menghindari penyalahgunaan lembaga antikorupsi sebagai alat viktimisasi politik (Suyatmiko dan Nicola, 2020).

\section{Penutup}

\section{Kesimpulan}

Setelah memahami dinamika skor CPI dengan didukung oleh penjelasan per indikator, maka bisa diperoleh kesimpulan bahwa:

1. Penurunan skor CPI 2020 sebanyak 3 poin dari tahun 2019, dari skor 40 ke 37, merupakan penurunan yang paling signifikan sepanjang delapan tahun terakhir. Turunnya skor CPI 2020 disebabkan oleh menurunnya sebagian besar indikator penyusun yang menurun tajam. Di mana lima diantaranya turun secara signifikan. Sedangkan tiga lainnya berada pada posisi yang stagnan dan hanya satu saja yang mengalami kenaikan. Meskipun tidak memberikan efek yang bisa mendongkrak nilai agregat CPI 2020.

2. Penurunan indeks persepsi korupsi tahun 2020 juga dipengaruhi oleh situasi pandemi Covid-19. Situasi ini menghadirkan krisis ganda, yakni krisis ekonomi dan krisis kesehatan. Korupsi yang merusak pelayanan publik saat terjadi krisis juga berpotensi sepanjang penanganan Covid-19 (Tranparency International Indonesia, 2021).

3. Indikator ekonomi, investasi dan demokrasi yang paling banyak mengalami penurunan skor menandakan bahwa relasi antara keputusan politik dengan kemudahan berusaha dan sikap negara terhadap lembaga antikorupsi menjadi salah satu faktor yang berpengaruh pada persepsi publik. Sehingga perlu upaya yang ekstra keras dalam memberantas korupsi. Sejumlah kajian antikorupsi di kawasan Asia Pasifik telah mengonfirmasi bahwa efektivitas kinerja antikorupsi di suatu negara sejatinya tidak sematamata ditentukan oleh kerja-kerja reformasi teknokratik administratif, melainkan lebih ditentukan oleh dinamika politik, pola relasi, dan pilihan cara pandang para elitenya dalam menjalankan tradisi politik dan kekuasaan itu sendiri (Quah, 2012).

\section{Saran}

Dari kesimpulan tersebut maka untuk peningkatan skor CPI dan upaya 
pemberantasan korupsi di masa mendatang harus mengacu pada perbaikan kualitas penegakan hukum, kondusifitas iklim usaha dan investasi serta yang tidak kalah pentingnya adalah penerapan integritas politik. Jaminan kebebasan sipil dan memperluas ruang demokrasi, terutama di masa pandemi juga menjadi hal yang tidak boleh diabaikan.

Sejumlah kebijakan yang berkaitan dengan pemangkasan perizinan kemudahan berusaha dan investasi yang diiringi dengan keterbukaan informasi pengadaan barang dan jasa, senantiasa harus diikuti dengan penegakan hukum yang tegas bagi pelaku kejahatan korupsi. Di mana pembenahan sistem masih harus dituntaskan ke depan, yaitu memutus relasi koruptif antara pejabat negara, pelayan publik, penegak hukum dan pebisnis. (Transparency International Indonesia, 2019)

Tentu penurunan skor ini memberikan banyak pelajaran berharga. Diantaranya adalah fokus area dalam pemberantasan korupsi tidak bisa dipisahkan satu sama lainnya. Di mana saat melakukan perbaikan iklim investasi maka sejalan dengan hal terebut diperlukan juga upaya penegakan integritas, etik dan hukum untuk mencegah risiko korupsi yang timbul. Termasuk diantaranya adalah menganulir sejumlah potensi dan risiko korupsi politik sehingga tidak timbul dampak yang merugikan masyarakat dan menjauhkan cita-cita bangsa Indonesia dari keadilan dan kesejahteraan sosial.

\section{Referensi}

Antara. (2021). Menkopolhukam Sudah Prediksi Indeks Persepsi Korupsi Indonesia Turun. Antara News. https://www.antaranews.com/beri ta/1972533/mahfud-md-sudahprediksi-indeks-persepsi-korupsiindonesia-turun
Aspinall, E., dan W. Berenschot. (2019). Democracy for Sale: Elections, Clientelism, and the State in Indonesia. First Edition. Cornell University Press. Ithaca. Terjemahan E. Riyadi. 2019. Democracy for Sale: Pemilihan Umum, Klientelisme, dan Negara di Indonesia. Cetakan 1. Yayasan Pustaka Obor Indonesia. Jakarta.

Bertelsmann Foundation Transformation Index. (2020). Governance Reports. Bertelsmann Foundation. https://www.btiproject.org/en/press.html. 12 Februari 2021.

Economist Intelligence Unit. (2020). Country Risk Service. Economist Intelligence Unit. https://www.eiu.com/n/solutions/ country-risk-service/. 12 Februari 2021.

Democracy Index 2020: In sickness and in health? Economist Intelligence Unit https://www.eiu.com/n/campaign s/democracy-index-2020/. $\quad 12$ Februari 2021.

Freedom House. (2019). Freedom in the World - Indonesia Country Report. Freedom House. https://freedomhouse.org/country /indonesia. 12 Februari 2021.

Hadiz, V. R. (2003). Reorganizing Political Power in Indonesia: A Reconsideration of so-called 'Democratic Transitions'. The Pacific Review 16.

Hamilton, A., dan C. Hammer. (2018). Can We Measure the Power of the Grabbing Hand? A Comparative Analysis of Different Indicators of Corruption. Policy Research Working Papers; World Bank. http://documents1.worldbank.org /curated/en/11328151551682874 
6/pdf/WPS8299.pdf. 12 Februari 2021.

IHS Markit. (2020). Economic Country Risk 2020. IHS Markit. https://ihsmarkit.com/industry/ec onomics-country-risk.html. 12 Februari 2021.

IMD World Competitiveness. (2020). World Competitiveness. IMD World Competitiveness. https://worldcompetitiveness.imd. org. 12 Februari 2021.

Johnston, M. (2005). Syndromes of Corruption: Wealth, Power and Democracy. Cambridge University Press.

Khan, M.H. (2010). Political Settlements and the Governance of GrowthEnhancing Institutions. SOAS Research Online.

Klitgaard, R. (1988). Controlling Corruption. University of California Press.

Komisi Pemberantasan Korupsi. (2018). Nota Sintesis Evaluasi GNPSDA KPK 2018. Komisi Pemberantasan Korupsi. https://www.kpk.go.id/images/pdf /LITBANG/Nota-Sintesis-EvaluasiGNPSDA-KPK-2018-Final.pdf. 15 Februari 2021.

(2019).

KPK Identifikasi 26 Poin yang Berisiko Melemahkan di RUU KPK. KPK.

https://www.kpk.go.id/id/berita/s iaran-pers/1255-kpk-identifikasi26-poin-yang-beresikomelemahkan-di-ruu-kpk. Februari 2021.

(2020). KPK Tahan Menteri Sosial Terkait Perkara Dugaan Suap Pengadaan Bansos Covid-19. KPK. https://www.kpk.go.id/id/berita/s iaran-pers/1986-kpk-tahan- menteri-sosial-terkait-perkaradugaan-suap-pengadaan-bansoscovid-19. 12 Februari 2021.

KPK Gelar Diskusi, Perkuat Komitmen Integritas Partai Politik. Komisi Pemberantasan Korupsi. https://www.kpk.go.id/id/berita/s iaran-pers/1941-kpk-gelar-diskusiperkuat-komitmen-integritaspartai-politik. 12 Februari 2021.

Laswell, H. (1936). Politics: Who Gets What, When, How? Published online by Cambridge University Press: 02 September 2013.

Mochtar, Z.A. (2021). Membaca Anjloknya IPK Indonesia. Media Indonesia. https://m.mediaindonesia.com/kol om-pakar/381416/membacaanjlok-ipk-indonesia. 12 Februari 2021.

Mongabay. (2020). Tidak hanya Finansial, Korupsi SDA Juga Berdampak Pada Perusakan Ruang. Mongabay. https://www.mongabay.co.id/202 0/05/23/tidak-hanya-finansialkorupsi-sda-juga-berdampakpada-perusakan-ruang/. Februari 2021.

Muhtadi, B. (2020). Kuasa Uang. Kepustakaan Populer Gramedia.

Mulholland, J., dan A. Sanit. (2020). The Weakening of Indonesia's Corruption Eradication Commission. East Asia Forum. https://www.eastasiaforum.org/2 020/01/28/the-weakening-ofindonesias-corruption-eradicationcommission/. 15 Februari 2021.

Mungiu-Pippidi, A. (2015). The Quest for Good Governance: How Societies Develop Control of Corruption. Cambridge University Press.

Political And Economic Risk Consultancy Ltd. (2018). PERC's 2018 Report on Corruption in Asia. PERC Asia. 
http://www.asiarisk.com/subscrib e/dataindx.html. 12 Februari 2021.

Pope, J. (2000). Confronting Corruption: The Element of National Integrity System. Copyright Jeremy Pope and Transparency International 2000. Terjemahan M. Maris. 2008. Strategi Memberantas Korupsi: Elemen Sistem Integritas Nasional. Transparency International Indonesia dan Yayasan Obor Indonesia. Jakarta.

Political Risk Service Group. (2020). December $2020 \quad$ Political Risk Reports. PRS Group. https://www.prsgroup.com/comin g-soon-in-our-december-2020political-risk-reports/. 12 Februari 2021.

Quah, J.S.T. (2009). Combating Corruption in the Asia-Pacific Countries: What Do We Knowand What Needs to be done? International Public Management Review 10 (1).

Robison, R., dan V. Hadiz. (2004). Reorganizing Power in Indonesia. Routledge Curzon. New York.

Rothstein, B. (2011). The Quality of Government: Corruption, Social Trust, and Inequality in International Perspective. The University of Chicago Press. Chicago and London.

SeratId. (2020). Marepus Corner: 55 Persen Anggota DPR Pebisnis. Serat Id. https://serat.id/2020/10/10/55persen-anggota-dpr-pebisnis/. 12 Februari 2021.

Suyatmiko, W.H. (2020). The Importance of Political Integrity In Indonesia. Transparency International. https://voices.transparency.org/th e-importance-of-political-integrityin-indonesia-36b6daf38e82. $\quad 12$ Februari 2021.
Suyatmiko, W.H., dan A. Nicola. (2020). Menakar Lembaga Antikorupsi: Studi Peninjauan Kinerja Komisi Pemberantasan Korupsi. Jurnal Antikorupsi INTEGRITAS 5: (2).

Transparency International. (2021). Global Higlights. Transparency International. https://www.transparency.org/en /news/cpi-2020-global-highlights. 12 Februari 2021.

(2021). CPI

2020 Asia Pacific. Transparency International.

https://www.transparency.org/en /news/cpi-2020-asia-pacific. 12 Februari 2021.

Health and Corruption. Transparency International. https://www.transparency.org/en /our-priorities/health-andcorruption. 12 Februari 2021.

Transparency International dan U4 Anti Corruption Resource Centre. (2012). Causes of Corruption in Indonesia. Transparency International.

https://www.transparency.org/file s/content/corruptionqas/338_Caus es_of_corruption_in_Indonesia.pdf. 13 Februari 2021.

Transparency International Indonesia. (2019). Siaran Pers. Transparency International Indonesia. https://riset.ti.or.id/corruptionperceptions-index2019/?preview=true. 28 Januari 2021.

(2021). Siaran Pers. Transparency International Indonesia website: https://riset.ti.or.id/indekspersepsi-korupsi-2020-korupsirespons-covid-19-dankemundurandemokrasi/?preview=true. $\quad 28$ Januari 2021. 
Umam, A.K. (2020). Lemahnya Komitmen Antikorupsi Presiden diAntara Ekspektasi Pembangunan Ekonomi dan Tekanan Oligarki. Jurnal Antikorupsi INTEGRITAS 5(2): 1-17.

Umam, A.K. (2021). Rapor Merah Kinerja Antikorupsi. Sindonews. 3 Februari 2021.

Varieties of Democracy. (2020). V-Dem Dataset - Version 11. V-Dem. https://www.vdem.net/en/data/data/v-demdataset/. 28 Januari 2021.

Vrushi, J., and R.M.B. Kukutschka. (2021). Why Fighting Corruption Matters In Times of Covid-19. https://www.transparency.org/en /news/cpi-2020-research-analysiswhy-fighting-corruption-mattersin-times-of-covid-19.

Winters, J. A. (2013). Oligarchy and Democracy in Indonesia. Online, SEAP Indonesia, 11-33. Ithaca, N.Y.
World Economic Forum. (2020). Reports. World Economic Forum. https://www.weforum.org/reports ?year=2020\#filter. 12 Februari 2021.

World Justice Project. (2020). Rule of Law Index. World Justice Project. https://worldjusticeproject.org/ab out-us/overview/what-rule-law. 12 Februari 2021.

World Bank Group. (2020). Doing Business 2020 - Indonesia. World Bank Group.

https://www.doingbusiness.org/co ntent/dam/doingBusiness/country /i/indonesia/IDN.pdf. 12 Februari 2021.

Zuniga, N., dan S. Mullard. 2018. Impact of Structural Adjustment Programmes on Corruption. Transparency International and U4 Anticorruption Resource Center. 
Wawan Heru Suyatmiko 